\title{
Digital technologies in the prevention of diabetic foot: a review on mobile applications
}

\section{Tecnologias digitais na prevenção de pé diabético: uma revisão sobre aplicativos móveis}

\section{Tecnologías digitales en la prevención del pie diabético: una revisión sobre aplicaciones móviles}

\author{
Sabado Gomes Dabó1, Maria Girlane Sousa Albuquerque Brandão 1*, Thiago Moura de Araújo', \\ Natasha Marques Frota', Vivian Saraiva Veras ${ }^{1}$
}

ORCID IDS

Dabó SG (D) https://orcid.org/0000-0002-2782-2106

Brandão MGSA (D) https://orcid.org/0000-0002-9925-4750

Araújo TM (D) http://orcid.org/0000-0002-8410-0337

Frota NM (D) https://orcid.org/0000-0001-8307-6542

Veras VS (D) https://orcid.org/0000-0003-3267-3712

\section{HOW TO CITE}

Dabó SG; Brandão MGSA; Araújo TM; Frota NM; Veras VS. Tecnologias digitais na prevenção de pé diabético: uma revisão sobre aplicativos móveis. ESTIMA, Braz. J. Enterostomal Ther., 18, 2020: e1420. https:// doi.org/10.30886/estima.v18.870_IN

\begin{abstract}
Objective: Analyze mobile applications developed for prevention of diabetic foot. Method: Integrative review, with searches in LILACS, BDENF, Scopus, Web of Science and PubMed databases, from 2000 to 2019. After eligibility criteria, the sample consisted of nine articles. Results: The mobile applications for prevention of diabetic foot are based on online foot monitoring through images, evaluation of thermal images of the feet, capture of images of the sole of the foot, recommendations for self-care with the feet and classification of the risk of diabetic foot. The analysis of the articles shows that the applications were considered a good prevention strategy. Conclusion: This study enabled the identification of nine mobile applications developed for prevention of diabetic foot, with predominance in the use of thermometry as the main measure for prevention and early detection of diabetic foot ulcers, with the use of thermal images and sensors associated with the mobile application.
\end{abstract}

DESCRIPTORS: Mobile applications. Diabetes mellitus. Diabetic foot. Enterostomal therapy.

\begin{abstract}
RESUMO
Objetivo: Analisar aplicativos móveis desenvolvidos para prevenção do pé diabético. Método: Revisão integrativa, com buscas nas bases de dados LILACS, BDENF, Scopus, Web of Science e PubMed, no período de 2000 a 2019. Após critérios de elegibilidade, a amostra constituiu-se de nove artigos. Resultados: Os aplicativos móveis para prevenção do pé diabético, se baseiam no monitoramento online dos pés por meio de imagens, avaliação de imagens térmicas dos pés, captura de imagens da planta do pé, recomendações de autocuidado com os pés e classificação do risco de pé diabético. A análise dos artigos evidencia que os aplicativos foram considerados como boa estratégia de prevenção. Conclusão: A realização deste estudo possibilitou a identificação de nove aplicativos móveis desenvolvidos para prevenção do pé diabético, com predomínio no uso da termometria como principal medida para prevenção e detecção precoce das úlceras do pé diabético, com utilização de imagens térmicas e sensores associados ao aplicativo móvel.
\end{abstract}

DESCRITORES: Aplicativos móveis. Diabetes mellitus. Pé diabético. Estomaterapia.

1. Universidade da Integração Internacional da Lusofonia Afro-Brasileira - Departamento de Enfermagem - Redenção (CE), Brasil.

*Correspondence author: girlane.albuquerque@yahoo.com.br

Received: Mar. 17, 2020 | Accepted: Apr. 30, 2020 


\section{RESUMEN}

Objetivo: Analizar aplicaciones móviles desarrolladas para la prevención del pie diabético. Método: Revisión Integrativa, con búsquedas en las bases de datos LILACS, BDENF, SCOPUS, Web of Science y PubMed, en el período 2000 a 2019. Después de los criterios de elegibilidad, la muestra consistió en nueve artículos. Resultados: Las aplicaciones móviles para la prevención del pie diabético se basan en el monitoreo en línea de los pies mediante imágenes, evaluación de imágenes térmicas de los pies, captura de imágenes del pie, recomendaciones para el autocuidado de los pies y clasificación del riesgo de pie. diabético El análisis de los artículos muestra que las aplicaciones se consideraron una buena estrategia de prevención. Conclusión: El desempeño de este estudio permitió la identificación de nueve aplicaciones móviles desarrolladas para la prevención del pie diabético, con un predominio en el uso de la termometría como la medida principal para la prevención y detección temprana de las úlceras del pie diabético, con el uso de fotografías térmicas y sensores asociados con la aplicación móvil.

DESCRIPTORES: Aplicaciones móviles. Diabetes mellitus. Pie diabético. Estomaterapia.

\section{INTRODUCTION}

The complications of diabetes mellitus (DM) can be both macro and microvascular and most often happen because of the difficulty in keeping glycemic rates under control $1^{1}$. Among the complications, diabetic neuropathy is the most frequent, characterized by clinical syndromes that affect different parts of the nervous system and present several clinical manifestations, which have as main outcome foot ulcers, which, associated with ischemia, deformities or infections, induce the so-called diabetic foot ${ }^{2}$.

Diabetic foot promotes decreased quality of life and loss of physical mobility, and in most cases can culminate in lower limb amputations and about 40 and $60 \%$ of nontraumatic amputations ${ }^{3}$.

As it is an eminently outpatient chronic control disease, health education plays a key role in preventing DM complications. Thus, people with DM need to routinely receive instructions on preventive self-care for foot injuries and regular foot care ${ }^{2}$.

The use of information and communication technologies (ICTs) can be a strong ally in the process of health education for people with DM in the prevention of diabetic foot, facing the existence of mobile applications that can help in the empowerment of users, improve the support of health care, increase efficiency in self-care and quality of life ${ }^{4}$.

Therefore, several mobile applications are being developed and validated, including applications for self-care and selfmonitoring of people with DM, with features that help in daily foot supervision, accessibility to treatment, health education, testing and diagnosis, which can combine the use of images, videos, audio and accessible language, which increases the opportunities and motivation for prevention of diabetic foot ${ }^{5-7}$.
Mobile applications can offer nurses the opportunity to strengthen ties with their clients and family members, and guide them to self-care, improve their scientific knowledge, assist during the nursing consultation in risk prevention, monitoring and control of complications, and thus increase the chances of prevention and early detection of foot changes 5 .

From the evolution of technological tools and the rise of health technologies, nurses and other health professionals should update themselves to learn about these technologies for education, prevention and health promotion of people with DM and increase their users' health care.

The objective of this study is to analyze mobile applications developed for prevention of diabetic foot.

\section{METHODS}

Integrative review-type study (IR), a research method that allows the synthesis and general conclusions of the state of knowledge on a given theme, in addition to providing support for decision making and improving clinical practice, and thus pointing out possible gaps that imply in conducting new studies on the thematic area in question ${ }^{8}$.

The conduction of the IR followed six steps: identification of the theme and selection of the research question; establishment of criteria for inclusion and exclusion of studies; categorization of studies; evaluation of studies included in the integrative review; interpretation of results and synthesis of the knowledge of the main results evidenced in the analysis of the articles included'.

The research question was elaborated according to the PICO strategy, an acronym which means "patient, intervention, comparison and outcome". It represents an important method for the elaboration of the guiding question 
and subsequent search for evidence in the literature ${ }^{10}$. Based on this strategy, this review considered "P" diabetes patients, "I" referred to the use of mobile applications, "C" there were no corresponding words, and "O" was associated with monitoring and prevention of diabetic foot.

Thus, the following guiding question was formulated: What mobile applications available in the literature have been developed for diabetic foot prevention?

The bibliographic survey took place from October 2019 to January 2020 in the following databases: Latin American and Caribbean Health Sciences Literature (LILACS), the Brazilian Nursing Database (BDENF), Scopus, Web of Science and PubMed. A crossover of the descriptors Mobile Applications (Aplicativos Móveis) AND Diabetes Mellitus (Diabetes Mellitus) AND Diabetic Foot (Pé Diabético), extracted from DeCS (Descriptor in Health Sciences) and $\mathrm{MeSH}$ (Medical Subject Headings) was performed.

The following criteria were chosen for the inclusion of the studies: articles available in full, in Portuguese, English and Spanish, that answered the guiding question of the study, published between 2009 and 2019. The exclusion criteria were repeated publications, editorials, manuals, books, theses, dissertations, monographs and review studies. An instrument adapted from $\mathrm{Ursi}^{11}$ was used to extract the articles. The instrument allows obtaining information on the identification of the article (title, language, year of publication, name of the journal), methodological characteristics of the study, the interventions measured, the results found and the levels of evidence.

When searching the articles, 297 articles were found on PubMed, 10 on Scopus, 9 on the Web of Science, 3 on LILACS and 3 on BDENF, totaling 322 articles. Then, a preselection of the articles identified in the searches was made by reading the title and the abstract. Three articles were excluded because they were not available, as well as 16 papers from congresses, 24 literature reviews, 4 books and 100 articles because they did not fit the inclusion criteria.

The remaining 175 articles were carefully read in order to identify key ideas and guidelines directed to the object of study. Of these, 13 repeated studies were excluded and 153 that did not answer the guiding question, which provided a final sample of 9 studies, according to PRISMA (Fig.1). The selection stages of the studies were independently performed by two authors of this review.

A third reading was also carried out to confirm the information obtained in the second reading and to deepen the analysis of each manuscript included in the research.

Table 1 shows the justification for the exclusion of the articles after identification in the databases and reading in full until the final sample of nine articles.

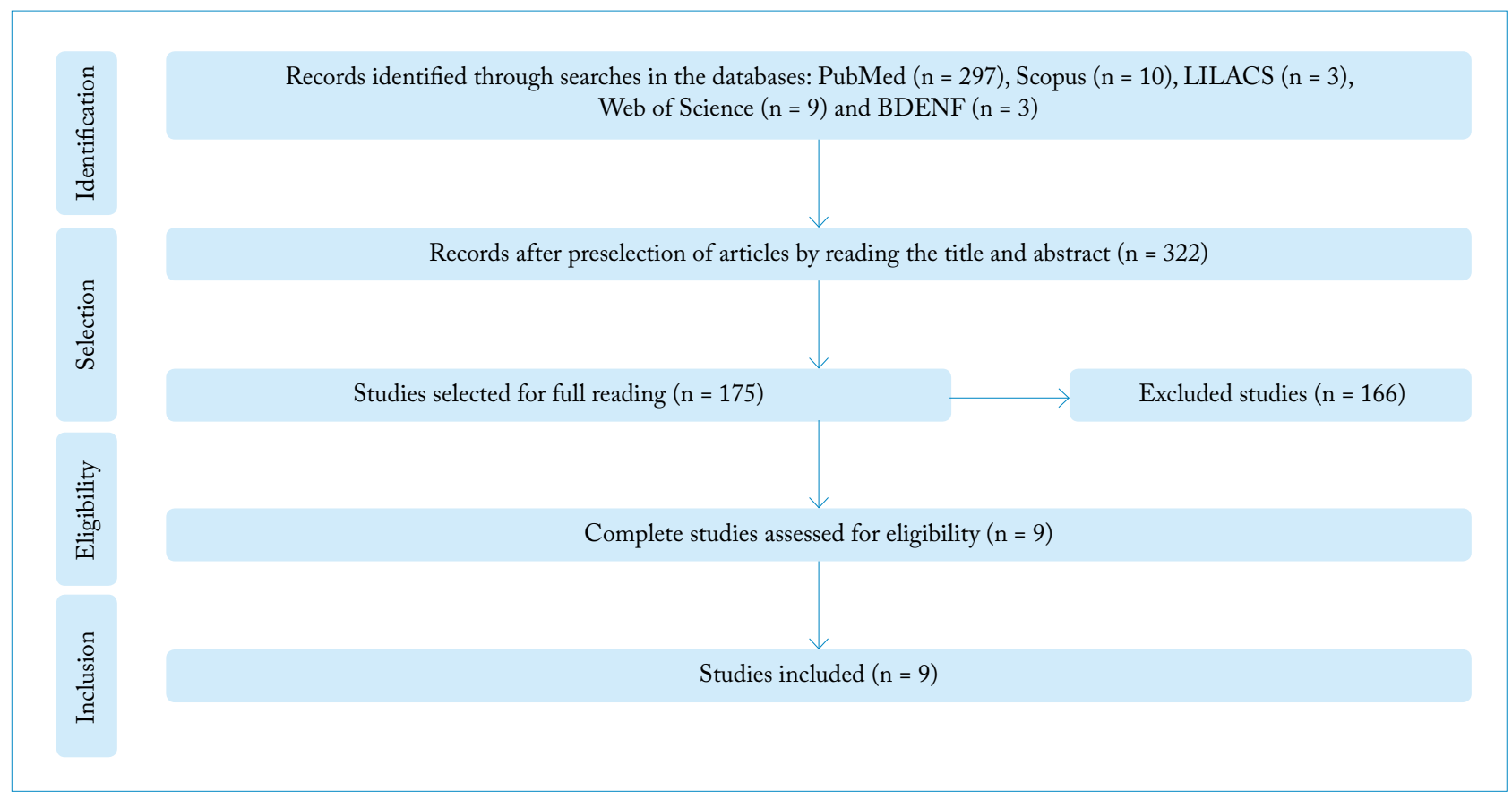

Figure 1. Flowchart of study selection according to Preferred Reporting Items for Systematic Reviews and Meta-Analyses (PRISMA 2009). 
Table 1. Justification for exclusion of articles after full reading.

\begin{tabular}{|c|c|c|c|c|c|c|}
\hline Articles & LILACS & Scopus & $\begin{array}{l}\text { Web of } \\
\text { Science }\end{array}$ & BDENF & PubMed & Total \\
\hline Selected & 03 & 10 & 09 & 03 & 150 & 175 \\
\hline Not suitable & 01 & 04 & 03 & 01 & 144 & 153 \\
\hline Repeated & 01 & 03 & 04 & - & 05 & 13 \\
\hline Final sample & 01 & - & 02 & - & 06 & 09 \\
\hline
\end{tabular}

\section{RESULTS}

The nine articles included in this integrative review are presented in Table 2, composed by title, authorship, year, objective, method, location of the study and level of evidence. When analyzing the quality of scientific evidence, it is noticeable that most articles $(n=5)$ have a level VI classification of evidence ${ }^{12}$.

Regarding the year of publication of the articles, one article was published in 2013, one in 2016, one published in 2017, four in 2018 and two in 2019. Regarding the language, eight articles were published in
English. There was diversification in the study scenario, which was developed in the following countries: Brazil $(\mathrm{n}=2)$, India $(\mathrm{n}=1)$, Germany $(\mathrm{n}=1)$, Peru $(\mathrm{n}=1)$, the Netherlands $(n=1)$, the United Kingdom $(n=1)$, the United Arab Emirates ( $\mathrm{n}=1)$ and the United States of America $(n=1)$.

There was a predominance of studies available in the PubMed database ( $\mathrm{n}=6)$. The LILACS and Web of Science databases presented, respectively, 1 and 2 publications. Regarding the category of publications, two studies were published in the area of nursing and seven studies were in the medical and biomedical area.

Table 2. Distribution of articles according to title, authorship, year, objective, method, location of the study and level of evidence. Redenção (CE), 2020.

\begin{tabular}{|c|c|c|c|c|c|}
\hline N. & Title & $\begin{array}{c}\text { Authors/ } \\
\text { Year }\end{array}$ & Objective & $\begin{array}{l}\text { Method/ } \\
\text { location }\end{array}$ & $\begin{array}{l}\text { Level of } \\
\text { evidence }\end{array}$ \\
\hline 1 & $\begin{array}{l}\text { SoleSCAN - mobile phone } \\
\text { based monitoring of foot } \\
\text { sole for callus formation } \\
\text { and the shoe insole for } \\
\text { pressure "hot spots" }\end{array}$ & $\begin{array}{l}\text { Dutta, Dutta } \\
(2013)^{13}\end{array}$ & $\begin{array}{l}\text { Monitoring of skin tissue in the foot } \\
\text { for callus or ulcer formation for early } \\
\text { prevention. }\end{array}$ & $\begin{array}{l}\text { Clinical trial } \\
\text { Randomized } \\
\text { India }\end{array}$ & Level II \\
\hline 2 & $\begin{array}{l}\text { Implementation of foot } \\
\text { thermometry plus mHealth } \\
\text { to prevent diabetic foot } \\
\text { ulcers: study protocol for a } \\
\text { randomized controlled trial }\end{array}$ & $\begin{array}{l}\text { Lazo-Porras et } \\
\text { al. }(2016)^{14}\end{array}$ & $\begin{array}{l}\text { Compare the incidence of diabetic } \\
\text { foot ulcer during the study period } \\
\text { between those who received only } \\
\text { thermometry and those who } \\
\text { received more text messages and } \\
\text { voice messages. }\end{array}$ & $\begin{array}{l}\text { Clinical study } \\
\text { Randomized } \\
\text { Peru }\end{array}$ & Level II \\
\hline 3 & $\begin{array}{l}\text { Mobile application for } \\
\text { ulcer detection }\end{array}$ & $\begin{array}{l}\text { Fraiwan et al. } \\
\qquad(2018)^{15}\end{array}$ & $\begin{array}{l}\text { Build a mobile thermal imaging system } \\
\text { that can be used as an indicator for } \\
\text { possible ulcers in development. }\end{array}$ & $\begin{array}{l}\text { Descriptive } \\
\text { study } \\
\text { United Arab } \\
\text { Emirates }\end{array}$ & Level VI \\
\hline 4 & $\begin{array}{l}\text { Promoting self-care of } \\
\text { diabetic foot ulcers through } \\
\text { a mobile phone app: } \\
\text { user-centered design } \\
\text { and evaluation }\end{array}$ & $\begin{array}{l}\text { Ploderer et al. } \\
(2018)^{17}\end{array}$ & $\begin{array}{l}\text { Assess the usability and potential } \\
\text { utility of mobile phone applications to } \\
\text { engage people with diabetic foot ulcers } \\
\text { in self-care. }\end{array}$ & $\begin{array}{l}\text { Qualitative } \\
\text { study } \\
\text { Netherlands }\end{array}$ & Level VI \\
\hline
\end{tabular}


Table 2. Continuation

\begin{tabular}{|c|c|c|c|c|c|}
\hline N. & Title & $\begin{array}{l}\text { Authors/ } \\
\text { Year }\end{array}$ & Objective & $\begin{array}{l}\text { Method/ } \\
\text { location }\end{array}$ & $\begin{array}{l}\text { Level of } \\
\text { evidence }\end{array}$ \\
\hline 5 & $\begin{array}{c}\text { Continuous temperature- } \\
\text { monitoring socks } \\
\text { for home use in patients } \\
\text { with diabetes: } \\
\text { observational study }\end{array}$ & $\begin{array}{l}\text { Reyzelman et al. } \\
\qquad(2018)^{16}\end{array}$ & $\begin{array}{l}\text { Assess the accuracy of } \\
\text { sensors used in everyday } \\
\text { wear socks, get feedback } \\
\text { from the wearer on the comfort } \\
\text { of the socks, incorporated } \\
\text { by sensors and examine whether } \\
\text { the observed temperatures relate } \\
\text { to clinical observations. }\end{array}$ & $\begin{array}{c}\text { Case study } \\
\text { United States of } \\
\text { America }\end{array}$ & Level VI \\
\hline 6 & $\begin{array}{c}\text { A new mobile application } \\
\text { for standardizing diabetic } \\
\text { foot images }\end{array}$ & Yap et al. $(2018)^{7}$ & $\begin{array}{l}\text { Test application reliability } \\
\text { when used with the same } \\
\text { diabetic feet on separate } \\
\text { occasions and in the hands of } \\
\text { two separate operators. }\end{array}$ & $\begin{array}{l}\text { Longitudinal } \\
\text { study } \\
\text { United Kingdom }\end{array}$ & Level VI \\
\hline 7 & $\begin{array}{l}\text { Rehabilitation technology } \\
\text { for self-care: Customised } \\
\text { foot and ankle exercise } \\
\text { software for people } \\
\text { with diabetes }\end{array}$ & $\begin{array}{l}\text { Ferreira et al. } \\
\qquad(2019)^{19}\end{array}$ & $\begin{array}{l}\text { Develop and validate software content } \\
\text { (desktop and mobile applications) } \\
\text { for self-management } \\
\text { and foot and ankle exercises } \\
\text { personalized for people with } \\
\text { diabetes and diabetic neuropathy. }\end{array}$ & $\begin{array}{l}\text { Quantitative } \\
\text { study } \\
\text { Brazil }\end{array}$ & Level VI \\
\hline
\end{tabular}

Study protocol for a randomized controlled trial to test for preventive effects 8 of diabetic foot ulceration by telemedicine that includes sensor-equipped insoles combined with photo documentation
Investigate the hypothesis that a twice daily recording of foot temperatures

Ming et al. $(2019)^{18}$ with the aid of the insole equipped with a sensor (Medixfeet Insole, Thorsis Technologies $\mathrm{GmbH}$ ) can reduce the risk of ulcer formation.

\section{Randomized}

clinical trial

Germany
Level II rang

\section{Mobile application for \\ 9 evaluation of feet in people with diabetes mellitus \\ Vêscovi et al. $(2017)^{5}$}

Describe the application development and
validation process for mobile
devices on risk assessment and rating of the feet of people with DM. . 
Table 3. Distribution of articles according to authorship, name, application function and main results.

\begin{tabular}{|c|c|c|c|}
\hline Authors & $\begin{array}{c}\text { Application } \\
\text { name }\end{array}$ & Application function & Main results \\
\hline $\begin{array}{l}\text { Dutta, Dutta } \\
(2013)^{13}\end{array}$ & SoleSCAN & $\begin{array}{l}\text { Online foot monitoring by means of an } \\
\text { insole that records photos and transfers the } \\
\text { information to a data server. }\end{array}$ & $\begin{array}{l}\text { The application was considered a good } \\
\text { prevention strategy, as it allows the early } \\
\text { detection of possible callus and foot } \\
\text { ulcers formation. }\end{array}$ \\
\hline $\begin{array}{l}\text { Lazo-Porras et } \\
\text { al. }(2016)^{14}\end{array}$ & TempStat & Capture thermal images of the feet. & $\begin{array}{c}\text { Thermometry can reduce the incidence } \\
\text { of diabetic foot. The application } \\
\text { presented an innovative and low-cost } \\
\text { preventive approach. }\end{array}$ \\
\hline $\begin{array}{l}\text { Fraiwan et al. } \\
\qquad(2018)^{15}\end{array}$ & FLIR ONE & $\begin{array}{l}\text { Obtain thermal images, process them and } \\
\text { analyze them to predict ulceration. }\end{array}$ & $\begin{array}{c}\text { The mobile system has been successful } \\
\text { in identifying foot temperature increases } \\
\text { and enables early interventions to prevent } \\
\text { diabetic foot. }\end{array}$ \\
\hline $\begin{array}{l}\text { Ploderer et al. } \\
\qquad(2018)^{17}\end{array}$ & My Foot Care & $\begin{array}{l}\text { It highlights personal goals to help motivate } \\
\text { patients in self-care and provides reminders } \\
\text { to enforce regular care. }\end{array}$ & $\begin{array}{l}\text { The application has widespread potential in } \\
\text { the prevention and treatment of foot ulcers } \\
\text { of people with diabetes. }\end{array}$ \\
\hline $\begin{array}{l}\text { Reyzelman et } \\
\text { al. }(2018)^{16}\end{array}$ & Stand-Alone & $\begin{array}{l}\text { Generate alerts when the user's feet show } \\
\text { temperature increase. }\end{array}$ & $\begin{array}{l}\text { Continuous monitoring of foot temperature } \\
\text { has proven to be a promising approach to } \\
\text { early intervention in the risk of developing } \\
\text { diabetic foot. }\end{array}$ \\
\hline $\begin{array}{l}\text { Yap et al. } \\
(2018)^{7}\end{array}$ & FootSnap & Obtain images of the sole of the foot. & $\begin{array}{l}\text { The application was successful in } \\
\text { standardizing the acquisition of photos } \\
\text { of the sole of the foot to observe foot } \\
\text { parameters and proved to be significant in } \\
\text { the prevention and management of diabetic } \\
\text { foot pathologies. }\end{array}$ \\
\hline $\begin{array}{l}\text { Ferreira et al. } \\
\qquad(2019)^{19}\end{array}$ & SoPeD & $\begin{array}{l}\text { Offer recommendations for foot self-care, } \\
\text { diabetes, diabetic foot and foot and ankle } \\
\text { exercises. }\end{array}$ & $\begin{array}{c}\text { The application has been validated and } \\
\text { showed a high degree of agreement among } \\
\text { experts, professionals and users, as an } \\
\text { application that can help in the prevention } \\
\text { of diabetic foot. }\end{array}$ \\
\hline $\begin{array}{l}\text { Ming et al. } \\
(2019)^{18}\end{array}$ & SPDFA & $\begin{array}{l}\text { Measure foot temperatures, provide } \\
\text { photographic documentation, and } \\
\text { assess well-being (quality of life) using an } \\
\text { interactive diary. }\end{array}$ & $\begin{array}{l}\text { The application has proven to be one of the } \\
\text { most cost-effective solutions for the early } \\
\text { detection of diabetic foot ulcers. }\end{array}$ \\
\hline $\begin{array}{l}\text { Vêscovi et al. } \\
\qquad(2017)^{5}\end{array}$ & CuidarTech & $\begin{array}{l}\text { Diabetic foot risk assessment and } \\
\text { classification. }\end{array}$ & $\begin{array}{c}\text { The application, through the nurses' } \\
\text { evaluation, proved to be reliable, adequate } \\
\text { and efficient for risk classification and } \\
\text { prevention of diabetic foot. }\end{array}$ \\
\hline
\end{tabular}

\section{DISCUSSION}

In this review, in response to the guiding question of the study, it was observed that different applications developed for prevention of diabetic foot were indicated as satisfactory by researchers in the analyzed publications. The studies were concerned with investigating and inserting in the applications the main causes that lead to ulceration and increased risk of developing diabetic foot.

Mobile applications presented thermal imaging as the predominant function. Some applications, besides performing thermometry, sent alerts through hyperthermia detection ${ }^{14-16}$. 
The use of mobile applications with thermometry can help reduce the incidence of ulcers that lead to diabetic foot. Thermometry measures the surface heat of the skin of the feet and is a promising low-cost emerging modality for assessing and managing early signs of diabetic foot development ${ }^{14,20}$.

Most complications of the diabetic foot can be aggravated by high temperatures on the soles of the feet and represent an early sign of diabetic foot syndrome. Studies conducted in Asia and Europe have shown that mobile applications that perform foot thermometry can be efficient in preventing diabetic foot ${ }^{13,18}$. Thus, the monitoring of the foot plant temperatures can be considered an effective method for early detection and possible prevention of diabetic foot ${ }^{18}$. This portrays the importance of mobile applications that can assist healthcare professionals in monitoring and preventing the emergence of changes that compromise the integrity of the feet. Thermal imaging is combined with the detection of plantar changes, which, associated with inadequate pressure points and footwear, increase the risk of ulceration development.

It is worth noting that mobile applications have the ability to bring together more than one function. Study in Germany developed a mobile application that has in addition to thermometry through insoles and sensors, a structure that provides all the photographic documentation of the feet and assessment of the well-being (quality of life) of the user, through the use of an interactive diary ${ }^{18}$. It is therefore perceived that mobile applications can group more than one function and contribute substantially to foot monitoring in order to prevent the emergence of diabetic foot.

Another application developed in India presented as a primary function the online foot monitoring through insoles that capture images and send them to a data server, which can be accessed by health professionals ${ }^{13}$.

Online monitoring of the skin tissue of the sole of the foot using insole and algorithm that processes images on smartphones and sends them to health professionals can be a cheap and effective way to detect the risk of developing calluses and pressure ulcers and prevent diabetic foot ${ }^{13}$. In this way, the use of insoles in shoes associated with mobile applications that process images can identify pressure points and hyperthermia in the feet, thus enabling early interventions.

An application developed in the UK to standardize the acquisition of photographs of the feet of people with diabetes and continuous monitoring by healthcare professionals was successful in standardizing the acquisition of photos of the sole of the foot, to observe relevant parameters of the plantar region and proved significant in the prevention, management and self-care of diabetic foot ${ }^{7}$.

Within this self-care perspective, researchers from the Netherlands developed a mobile application designed for users with DM to motivate and engage them in self-care. The application encourages the use of the mobile phone to take photos of the feet, which applies visual analysis to these photos and extracts information, allowing users and their caregivers to monitor them. In addition, it highlights personal goals to help motivate users with DM and provides reminders that encourage regular foot care ${ }^{17}$.

Brazilian study with similar scope validated mobile application that allows self-care and personalized care for patients by offering recommendations for self-care with the feet, diabetes, diabetic foot and foot and ankle exercises. Users receive online recommendations for foot care, information on DM and diabetic neuropathy, selfassessment of the foot according to the main changes (calluses, deformities and injuries), as well as exercises for the feet and ankles, in order to strengthen the muscles and improve movement ${ }^{19}$.

For this, the use of DM self-management applications was positively associated with self-care behavior, promoting beneficial lifestyle changes, with the ability to prevent complications such as diabetic foot ${ }^{21}$.

The adoption of educational practices as a strategy in the treatment of people with DM and foot at neuropathic risk aims at an emancipatory perspective, i.e., self-care. This perspective has been present in most studies because it goes beyond the curative model and increases the individual's knowledge about the disease, healthier living habits and regular foot care; this is because, besides improving the quality of life, it increases the individual's autonomy in the face of the disease.

A study consulted indicates that it is necessary to expand the knowledge and understanding of the nurses regarding the importance of assessing the feet of people with DM and accompany them at all levels of health care, in addition to instructing people with DM for self-care, since nursing has been going through several transformations with technological advances and should take advantage of mobile technologies to increase health promotion practices ${ }^{5}$. 
In this understanding, to assist the work of nurses in the care of people with DM, a Brazilian study has developed a software that provides nurses with a tool that helps them to assess and classify the risk of developing diabetic foot. The application, according to evaluation of judges and nurses, is functional, reliable, appropriate and efficient to classify the risk of developing diabetic foot and thus enable early interventions5. In the current health and technology scenarios there are several ICTs that can help to determine the risk of ulcers that culminate in diabetic foot. Most are portable, easy-to-handle, interactive, noninvasive technologies that do not require an expert to use, and allow users to track their foot care in any geographic location. These already tried and tested tools enable improvement by advancing technological resources and bring the subject closer to self-care, with the registration of photos, use of insoles for thermometry and in the answers to online surveys.

Thus, several applications in portable devices can facilitate the prevention of diabetic foot and improve the quality of life of people with $\mathrm{DM}^{22}$.

New updated studies are certainly needed to guide both decisions about the adoption (by users) or recommendation (by the responsible health team) of the most appropriate applications for use in self-care and prevention of diabetic foot, as well as to point ways for the development of new tools, or even the improvement of existing ones, testing the usability, acceptance and cost of applications.

Although the article presents limitations, such as the exclusion of articles unavailable in the databases, there were nine mobile applications that can be used by users and health professionals in the prevention of diabetic foot.

\section{CONCLUSION}

This study allowed the analysis of nine mobile applications developed for prevention of diabetic foot. There was a predominance in the use of thermometry as the main measure for prevention and early detection of diabetic foot ulcers, with the use of thermal images and sensors associated with the mobile application. In addition to obtaining images, other applications included goals, instructions on DM and foot care, interactive diary, risk rating, foot and ankle exercises, alarms, data transfer and storage.

\section{AUTHOR'S CONTRIBUTION}

Conceptualization, Dabó SG, Brandão MGSA and Veras VS; Methodology, Dabó SG and Brandão MGSA; Investigation, Dabó SG and Brandão MGSA; Writing Original Draft, Dabó SG, Brandão MGSA and Veras VS; Writing - Review and Editing, Dabó SG, Brandão MGSA, Araújo TM, Frota NM and Veras VS; Supervision, Veras VS.\& Edição, Dabó SG, Brandão MGSA, Araújo TM, Frota NM e Veras VS; Supervisão, Veras VS.

\section{REFERENCES}

1. Gomes DM, Dazio EMR, Paraizo CMS, Brito MVN, Gonçalves JS, Fava SMCL. Ressignificação do cuidado de uma pessoa com diabetes e pé diabético: relato de experiência. Rev Enferm Cent-Oeste Min. 2018;8:e1509. https://doi org/10.19175/recom.v8i0.1509

2. Sociedade Brasileira de Diabetes. Diretrizes da Sociedade Brasileira de Diabetes 2019-2020. São Paulo: Clannad; 2019. [cited on 10 Jan 2020]. Available at: https://www diabetes.org.br/profissionais/images/DIRETRIZES COMPLETA-2019-2020.pdf

3. Padilha AP, Rosa LM, Schoeller SD, Junkes C, Mendez $\mathrm{CB}$, Martins MMFPS. Care manual for diabetic people with diabetic foot: construction by Scoping Study. Texto Contexto - Enferm. 2018;26(4):e2190017. https://doi org/10.1590/0104-07072017002190017
4. Chaves ASC, Oliveira GM, Jesus LMS, Martins JL, Silva VC. Uso de aplicativos para dispositivos móveis no processo de educação em saúde: reflexos da contemporaneidade. Rev Humanid Inov. 2018;5(6):34-42. https://doi.org/10.20873/ uft.2447-4266.2018v4n6p826

5. Vêscovi SJB, Caniçali Primo C, Sant'Anna HC, Bringuete MEO, Rohr RV, Prado TN, et al. Mobile application for evaluation of feet in people with diabetes mellitus. Acta Paul Enferm. 2017;30(6):607-13. https://doi.org/10.1590/19820194201700087

6. Scarcella MFS. Elaboração e desenvolvimento de aplicativo móvel para autocuidado e automonitoramento do pé diabético [Dissertação]. [Belo Horizonte]: Universidade Federal de Minas Gerais; 2017 
7. Yap MH, Chatwin KE, Ng C-C, Abbott CA, Bowling FL, RajbhandariS, etal. Anew mobileapplication for standardizing diabetic foot images. J Diabetes Sci Technol. 2018;12(1):16973. https://doi.org/10.1177/1932296817713761

8. Correia BC, Trindade JK, Almeida AB. Fatores correlacionados à automedicação entre os jovens e adultos: uma revisão integrativa da literatura. Rev Inic Cient Ext. 2019;2(1):57-61.

9. Mendes KDS, Silveira RCCP, Galvão CM. Revisão integrativa: método de pesquisa para a incorporação de evidências na saúde e na enfermagem. Texto Contexto - Enferm. 2008;17(4):758-64. https://doi.org/10.1590/S0104-07072008000400018

10. Santos CAC, Pimenta CAM, Nobre MRC. The PICO strategy for the research question construction and evidence search. Rev Latino-Am Enfermagem. 2007;15(3):508-11. https://doi. org/10.1590/S0104-11692007000300023

11. Ursi ES. Prevenção de lesões de pele no perioperatório: revisão integrativa da literatura [Dissertação]. [Ribeirão Preto]: Universidade de São Paulo; 2005.

12. Polit DF, Beck CT. Fundamentos de Pesquisa em Enfermagem: Avaliação de Evidências para a Prática da Enfermagem. $7^{a}$ ed. Porto Alegre: Artmed; 2011.

13. Dutta A, Dutta A. SoleSCAN - mobile phone based monitoring of foot sole for callus formation and the shoe insole for pressure "hot spots". 2013 IEEE Point-of-Care Healthcare Technologies (PHT); 2013 Jan. 16-18; Bangalore: IEEE; 2013. https://doi.org/10.1109/PHT.2013.6461354

14. Lazo-Porras M, Bernabe-Ortiz A, Sacksteder KA, Gilman $\mathrm{RH}$, Malaga G, Armstrong DG, et al. Implementation of foot thermometry plus mHealth to prevent diabetic foot ulcers: study protocol for a randomized controlled trial. Trials. 2016;17:206. https://doi.org/10.1186/s13063-016-1333-1

15. Fraiwan L, Ninan J, Al-Khodari M. Mobile application for ulcer detection. Open Biomed Eng J. 2018;12:16-26. https://doi. org/10.2174/1874120701812010016
16. Reyzelman AM, Koelewyn K, Murphy M, Shen X, Yu E, Pillai $\mathrm{R}$, et al. Continuous temperature-monitoring socks for home use in patients with diabetes: observational study. J Med Internet Res. 2018;20(12):e12460. https://doi. org/10.2196/12460

17. Ploderer B, Brown R, Seng LSD, Lazzarini PA, van Netten JJ. Promoting self-care of diabetic foot ulcers through a mobile phone app: user-centered design and evaluation. JMIR Diabetes. 2018;3(4):e10105. https://doi.org/10.2196/10105

18. Ming A, Walter I, Alhajjar A, Leuckert M, Mertens PR. Study protocol for a randomized controlled trial to test for preventive effects of diabetic foot ulceration by telemedicine that includes sensor-equipped insoles combined with photo documentation. Trials. 2019;20:521. https://doi. org/10.1186/s13063-019-3623-x

19. Ferreira JSSP, Sacco ICN, Siqueira AA, Almeida MHM, Sartor CD. Rehabilitation technology for self-care: Customised foot and ankle exercise software for people with diabetes. PLoS ONE. 2019;14(6):e0218560. https://doi.org/10.1371/journal. pone.0218560

20. Skafjeld A, Iversen MM, Holme I, Ribu L, Hvaal K, Kilhovd BK. A pilot study testing the feasibility of skin temperature monitoring to reduce recurrent foot ulcers in patients with diabetes - a randomized controlled trial. BMC Endocr Disord. 2015;15:55. https://doi.org/10.1186/s12902-015-0054-x

21. Kebede MM, Pischke CR. Popular diabetes apps and the impact of diabetes app use on self-care behaviour: A survey among the digital community of persons with diabetes on social media. Front Endocrinol. 2019;10:135. https://doi. org/10.3389/fendo.2019.00135

22. Martín-Vaquero J, Encinas AH, Queiruga-Dios A, Bullón JJ, Martínez-Nova A, González JT, et al. Review on wearables to monitor foot temperature in diabetic patients. Sensors. 2019;19(4):776. https://doi.org/10.3390/s19040776 